\title{
Tingkat Herbivori Daun Mangrove Avicennia marina (Forssk.) Vierh. Dan Rhizophora mucronata Di Desa Kaliwlingi, Kecamatan Brebes, Kabupaten Brebes, Jawa Tengah
}

\author{
Eva Widayanti ${ }^{\star}$, Nirwani Soenardjo, Raden Ario \\ Departemen IImu Kelautan, Fakultas Perikanan dan IImu Kelautan, Universitas Diponegoro \\ Jl. Prof.H.Soedarto S.H, Tembalang,Semarang, Jawa Tengah 50275 Indonesia \\ *Corresponding author, e-mail : evawidayanti24@gmail.com
}

\begin{abstract}
ABSTRAK : Herbivori pada daun mangrove merupakan salah satu faktor penyebab berkurangnya luasan daun mangrove sehingga daerah fotosintesis menjadi berkurang dan akan mempengaruhi kondisi tanaman mangrove secara keseluruhan. Tujuan dari penelitian ini yaitu mengetahui tingkat herbivori daun Avicennia marina dan Rhizophora mucronata berdasarkan spesies, umur daun dan tinggi pohon di Desa Kaliwlingi, Kecamatan Brebes, Kabupaten Brebes. Penelitian ini dilakukan pada bulan Juni-Desember 2018. Metode yang digunakan dalam penelitian ini adalah metode deskriptif, sedangkan dalam penentuan lokasi pengambilan sampel dilakukan dengan metode purposive. Sampel daun dari spesies Avicennia marina dan Rhizophora mucronata diambil dari tiga kategori tinggi tanaman yang berbeda, yaitu: $<1 \mathrm{~m}, 1-<3 \mathrm{~m}$, dan 3-5 $\mathrm{m}$, masing-masing sebanyak 10 pohon sebagai ulangan. Daun dipisahkan berdasarkan umur daun (muda dan tua) dan kondisi daun (utuh dan tua). Total daun yang diambil masing-masing 10\% dari setiap pohon. Berdasarkan hasil penelitian, menunjukkan rerata nilai setiap spesies, umur daun dan tinggi pohon didapatkan tingkat herbivori pada $A$. marina yaitu $7,36 \%$ kisaran $(0,10-29,36 \%)$ sampai dengan $13,26 \%$ kisaran $(0,06-48,46 \%)$ sedangkan pada $R$. mucronata yaitu 5,93\% kisaran $(0,23-21,59 \%)$ sampai dengan $19,69 \%$ kisaran $(1,10-47,06 \%)$.
\end{abstract}

Kata Kunci : A. marina; R. mucronata; Herbivori; Kaliwlingi

\section{Herbivory Level of Mangrove Leaves Avicennia marina (Forssk.) Vierh. And Rhizophora mucronata In Kaliwlingi Village, Brebes District, Brebes Regency, Central Java}

\begin{abstract}
Herbivory in mangrove leaves is one of the factors causing reduced area of mangrove leaves so that the photosynthetic area becomes reduced and will affect the condition of the mangrove as a whole. The research is aiming to find out the herbivory level of herbivory Avicennia marina and Rhizophora mucronata based on the species, age, and the tree-height in Kaliwlingi Village, Brebes District, Brebes. The research is conducted in June-December 2018. The methodology is descriptive method, while the sample location decided with purposive method. The leaf sample from Avicennia marina and Rhizophora mucronata is taken from three different highcategorized plants there are: $<1 \mathrm{~m}, 1-<3 \mathrm{~m}$ and 3-5 $\mathrm{m}$, with 10 trees for each categories as the repetition. The leaf differs based on the ages of leaf (young leaf and old leaf), and the completion of the leaf condition. It takes $10 \%$ from each trees in total. The result show the average value of each spesies, age and the tree-height, it is obtained the herbivory level from $A$. marina is $7,36 \%$ in range $(0,10-29,36 \%)$ till $13,36 \%$ in range $(0,06-48,46 \%)$ while from $R$.mucronata is $5,93 \%$ in range $(0,23-$ $21,59 \%)$ till $19,69 \%$ in range $(1,10-47,06 \%)$.
\end{abstract}

Keywords: A. marina; R. mucronata; Herbivory; Kaliwlingi

\section{PENDAHULUAN}

Mangrove berperan dalam siklus nutrien atau unsur hara pada habitatnya, hal inilah yang menjadikan vegetasi mangrove sebagai tempat hidup, berlindung serta berkembang biak bagi fauna seperti amfibi, reptil, burung, ikan, primata, serangga dan sebagainya. Fauna yang terdapat pada vegetasi mangrove melakukan hubungan simbosis terhadap tumbuhan mangrove 
contohnya dengan memakan daun mangrove. Daun mangrove merupakan penyuplai bahan organik yang sangat tinggi dari total bahan organik yang ada di perairan, keberadaan serasah daun mangrove yang kaya akan karbon dan nitrogen berperan penting dalam rantai makanan di perairan (Kitamura et al., 1997; Muharam, 2014).

Herbivori merupakan peristiwa memakan seluruh atau sebagian jaringan tumbuhan oleh konsumen (herbivor) (Murphy, 1990). Herbivori daun menyebakan berkurangnya luasan daun mangrove sehingga daerah fotosintesis menjadi berkurang dan akan mempengaruhi kondisi tanaman mangrove secara keseluruhan, sehinga mempengaruhi pertumbuhan vegetasi. Herbivori pada daun mangrove juga mengurangi peran mangrove sebagai penghasil serasah sehingga produktivitas perairan berkurang karena kurangnya sumbangan bahan organik. Penurunan produktivitas perairan yang disebabkan pemangsaan daun mangrove bisa mencapai 5-20\%, sehingga tingkat herbivori juga dapat dijadikan indikator kondisi dan kesehatan vegetasi mangrove (Fransworth dan Ellison, 1996). Mengingat peranan penting vegetasi mangrove sebagai pendukung lingkungan melalui serasah daun, maka penelitian ini dilakukan untuk mengetahui tingkat herbivori daun mangrove pada kategori spesies, tinggi pohon dan umur daun mangrove.

Kabupaten Brebes merupakan salah satu kabupaten yang terletak di pesisir Pantai Utara Jawa Tengah yang secara geografis terletak pada 06 $48^{\prime} 2^{\prime \prime}$ LS dan $109^{\circ} 2^{\prime} 12^{\prime \prime}$ LU. Ekosistem mangrove Desa Kaliwlingi, Kecamatan Brebes, Kabupaten Brebes merupakan ekosistem mangrove hasil rehabilitasi. Kerusakan yang terjadi sebelumnya, disebabkan konversi lahan mangrove menjadi tambak udang windu. Hasil upaya rehabilitasi yang dilakukan didominasi spesies Avicennia marina dan Rhizophora mucronata. Lokasi penanaman yang berbeda-beda, serta pada waktu berbeda-beda pula diduga akan berpengaruh pada tingkat herbivori daun sehingga diduga tingkat herbivori daun pada setiap spesies mangrove memiliki nilai berbedabeda.

Tujuan penelitian ini untuk mengetahui tingkat herbivori daun Avicennia marina dan Rhizophora mucronata berdasarkan spesies, umur daun dan tinggi pohon di Desa Kaliwlingi, Kecamatan Brebes, Kabupaten Brebes.

\section{MATERI DAN METODE}

Materi utama penelitian ini adalah daun Avicennia marina dan Rhizophora mucronata yang diambil secara acak pada setiap pohon sampel yang sesuai dengan kategori. Daun diambil dari vegetasi mangrove Desa Kaliwlingi, Kecamatan Brebes, Kabupaten Brebes. Lokasi penelitian ditentukan melalui metode purposive dengan mempertimbangkan keberadaan spesies dominan yang sesuai dengan kategori tinggi pohon dan umur daun (daun tua dan daun muda) (Etikan et al., 2016).

Pengambilan sampel daun dilakukan pada dua jenis mangrove yang mendominasi pada lokasi yaitu Avicennia marina dan Rhizophora mucronata dengan tiga kategori tinggi pohon yaitu $<1 \mathrm{~m}, 1-<3 \mathrm{~m}$, dan 3-5 m. Masing-masing kategori dipilih sebanyak sepuluh pohon secara acak sebagai ulangan. Pengambilan sampel dilakukan dengan memetik daun secara acak, kecuali bagian yang masih kuncup sebanyak $10 \%$ meliputi daun muda dan tua. Pengambilan sampel sebanyak 10\% mempertimbangkan waktu, teknis, dan jumlah variabel (Pribadi, 1998).

Pengambilan data herbivori dilakukan dengan memisahkan daun berdasarkan kategori spesies, tinggi pohon, umur (tua atau muda) dan kondisi (rusak atau utuh), kemudian sampel daun didokumentasikan (Robot et al., 2018). Menurut Septyaningsih et al. (2014), kategori kerusakan daun ditandai dengan adanya bekas herbivori yaitu hilangnya sebagian luasan daun akibat gigitan atau pelubangan. Hasil foto sampel daun diolah menggunakan software Image-J untuk mengetahui nilai luas area daun dan Measure Picture untuk mengetahui panjang dan lebar daun.

\section{Analisis Data}

Analisis regresi yang digunakan bertujuan untuk mengetahui hubungan nilai luas area daun (y) terhadap nilai panjang dan lebar daun (x) dengan rumus persamaan regresi menggunakan SPSS 24. Persamaan regresi kemudian digunakan untuk memperkirakan luas daun imajiner daun yang rusak. Persamaan regresi yang digunakan sebagai berikut: 


$$
(Y=a+b x)
$$

Keterangan: $Y$ : luas daun $\left(\mathrm{cm}^{2}\right)$; a: konstanta; $\mathrm{x}$ : panjang $(\mathrm{cm}) \mathrm{x}$ lebar $(\mathrm{cm})$; b: koefisien $\mathrm{x}$ 1984:

Persentase luas daun yang dimangsa herbivor dapat diketahui melalui persamaan Lowman,

$$
\left(1,00-\frac{A L A}{P L A}\right) \times 100 \%=\% \text { herbivori }
$$

Keterangan: PLA = Luasan daun imaginer $\left(\mathrm{cm}^{2}\right) ; \mathrm{ALA}=$ Luasan daun yang tersisa $\left(\mathrm{cm}^{2}\right)$

Persen tingkat herbivori yang didapat kemudian diklasifikasikan menurut kelas kerusakan untuk mempermudah interpretasi data, Menurut Cooke et al. (1984), kelas kerusakan persentase tingkat herbivori dibagi menjadi delapan kelas (Tabel 1).

Tabel 1. Kelas Kerusakaan Persentase Tingkat Herbivori

\begin{tabular}{cc}
\hline Kelas Kerusakan & Persentase Tingkat Herbivori \\
\hline 1 & $<2,5 \%$ \\
2 & $2,5 \%-5 \%$ \\
3 & $5,1 \%-10 \%$ \\
4 & $10,1 \%-20 \%$ \\
5 & $20,1 \%-40 \%$ \\
6 & $40,1 \%-60 \%$ \\
7 & $60,1 \%-80 \%$ \\
8 & $>80 \%$ \\
\hline
\end{tabular}

Sumber : Cooke et al. (1984)

HASIL DAN PEMBAHASAN

Hasil penelitian di Desa Kaliwlingi menunjukkan tingkat herbivori spesies $A$. marina sebesar $8,98 \%$ dan R. mucronata sebesar $13,76 \%$. Hasil tersebut dapat ditunjukkan pada (Tabel 2).

Tabel 2. Rata-rata Tingkat Herbivori (\%) Jenis A. marina dan R. mucronata Berdasarkan Umur Daun dan Tinggi Tanaman.

Tinggi pohon $(\mathrm{m})$

A. Marina

$\begin{array}{cc}<1 \mathrm{~m} & 7,36 \\ & (0,10-29,36) \\ 1-<3 \mathrm{~m} & 7,68 \\ & (0,60-36,78) \\ 3-5 \mathrm{~m} & 9,99 \\ & (0,02-28,21)\end{array}$

R.mucronata
$<1 \mathrm{~m}$
12,96
$1-3 m$
3-5 m
$(1,18-27,90)$
12,13
$(0,10-33,73)$
18,63
(2,33-37,66)

TuaRerata

(\%)

$$
\begin{gathered}
(0,27-24,73) \\
8,02 \\
(0,01-28,34) \\
13,26 \\
(0,06-48,46)
\end{gathered}
$$

13,22

$(0,48-33,63)$

19,69

$(1,10-47,06)$

Jumlah daun yang mengalami kerusakan pada spesies $A$. marina lebih banyak, namun presentase tingkat herbivori yang dihasilkan lebih sedikit dibanding kerusakan pada daun $R$. mucronata. Hal ini karena pelubangan yang terjadi pada setiap daun $R$. mucronata lebih besar dibanding daun $A$. marina. Faktor lain yang mempengaruhi adalah pohon $A$. marina dijumpai 
tumbuh mengelompok, dengan jarak antar pohon lebih rapat dibanding $R$. mucronata. Tumbuhan yang memiliki jarak antar pohon lebih rapat akan memungkinkan herbivor berpindah tempat dengan mudah dan lebih memiliki banyak pilihan serta energi yang dibutuhkan herbivor lebih sedikit. Hal sebaliknya terjadi pada pohon yang tumbuh dengan jarak antar pohon jauh, akan menyulitkan herbivor untuk berpindah tempat dan membutuhkan tenaga lebih besar, sehingga herbivor akan lebih memilih tetap berada pada tumbuhan tersebut. Kondisi saat berada di lapangan bahwa vegetasi $A$. marina tumbuh mengelompok sedangkan $R$. mucronata tumbuh berjauhan. Hal ini sesuai dengan pernyataan Johnstone (1981) bahwa tumbuhan dengan kondisi lebih rapat memungkinkan herbivora lebih mudah berpindah tempat.

Faktor lain yang diduga menjadi penyebab adalah tingkat penggenangan. Keberadaan $R$. mucronata dalam habitat mangrove Desa Kaliwlingi sedikit lebih dekat dengan daratan, sedangkan A. marina langsung berhadapan dengan laut, keadaan ini dapat mempengaruhi tingkat herbivori pula. Daun yang mengalamii penggenangan akan mengalamii penurunan serangga herbivor dibandingkan dengan daun yang terbukai. Stowe (1995) menjelaskan bahwa daun yang mengalami penggenangan akan mengalami penurunan serangga herbivor dibanding daun yang tidak terkena penggenangan. Penggenangan secara periodik mempunyai pengaruh negatif terhadap tingkat herbivori akibat adanya perubahan keseimbangan garam dan penurunan aktivitas fotosintesis pada bagian yang tergenang. Penggenangan menyebabkan herbivor yang berasal dari jenis serangga berkurang, hal ini karena meningkatnya kadar garam daun serta terhalangnya serangga tersebut pada saat akan menempatkan telurnya pada daun.

Hasil penelitian tingkat herbivori ini sesuai dengan pernyataan Fransworht dan Ellison (1991), bentuk adaptasi dari spesies Avicennia marina adalah dengan mengeluarkan garam di bagian daun sedangkan spesies Rhizophora mucronata mengeluarkan garam di bagian akar, hal ini menyebabkan herbivor daun akan lebih memilih daun Rhizophora mucronata dibanding spesies Avicennia marina.

Tingkat herbivori berdasarkan spesies dalam penelitian ini lebih besar dibanding penelitian Amalia (2018) di Desa Timbulsloko, Demak dengan spesies $A$. marina sebesar $8,26 \%$ dan $R$. mucronata sebesar 9,49\%; Septyaningsih et al. (2014) di Segara Anakan Cilacap dengan spesies A. marina sebesar 7,46\%; dan Soenardjo (2013) dengan tingkat herbivori spesies $A$. marina sebesar 7,92\%; namun lebih kecil dari penelitian Nurcahyadi (2003) di Desa Teluk Awur Jepara dengan tingkat herbivori spesies $R$. mucronata sebesar $14,91 \%$. Uraian diatas menunjukkan bahwa meskipun spesies sama namun terdapat perbedaan tingkat herbivori di masing-masing lokasi. Perbedaan tersebut diduga dipengaruhi masing-masing predator pada setiap lokasi. Hal ini sesuai dengan pernyataan Robertson dan Duke (1987) bahwa perbedaan lokasi menyebabkan perbedaan serangga predator pada daun mangrove.

Berdasarkan distribusi kelas kerusakan yang terjadi pada daun tua $A$. marina dan daun muda $A$. marina dapat diketahui bahwa pada daun muda memiliki kerusakan tertinggi pada Kelas IV dengan kategori tinggi pohon 3-5 m, sedangkan kerusakan terendah terjadi pada kelas kerusakan $\mathrm{V}$ dengan kategori tinggi pohon $<1 \mathrm{~m}$, sedangkan daun tua $A$. marina kerusakan terbanyak terjadi pada Kelas III dengan kategori tinggi pohon $<1 \mathrm{~m}$. Kerusakan terendah terjadi pada Kelas VI, dimana kerusakan yang terjadi hanya pada kategori ketinggian 3-5m dapat dilihat pada (Gambar 1).

Daun muda dan tua $R$. mucronata mengalami kerusakan tertinggi pada Kelas kerusakan yang sama yaitu kelas IV namun pada daun muda lebih banyak terjadi pada kategori tinggi pohon 3-5m, sedangkan pada daun tua pada kategori tinggi pohon 1-3 m. Kelas kerusakan terendah daun muda dan daun tua terjadi pada kelas yang sama yaitu Kelas I, namun pada daun tua pada Kelas VI yang terjadi kerusakan hanya pada kategori tinggi pohon 3-5m (Gambar 2).

Kelas kerusakan yang dihasilkan termasuk pada kedua spesies terjadi pada Kelas I $(<2,5 \%)$, Kelas II (2,5\%-5,0\%), Kelas III (5,1\%-10,0\%), Kelas IV (10,1\%-20,0\%), Kelas V (20,1\%-40,0\%) dan Kelas VI (40,1\%-60,0\%), dengan kelas kerusakan tertinggi terdapat pada Kelas IV. Kelas kerusakan yang terjadi akan berpengaruh terhadap produktivitas primer mangrove dan perairan. Hilangnya jaringan daun akan mengganggu proses fotosintesis sehingga berpengaruh terhadap pertumbuhan. McNaughton (1983) menjelaskan pula bahwa herbivori akan mempengaruhi reproduksi secara langsung karena rusaknya jaringan reproduksi. Herbivori pada tingkat yang intensif dapat menurunkan 2,8\%-3,5\% produktivitas serasah yang jatuh ke lantai hutan. Kelas 
kerusakan yang terjadi menunjukkan pelubangan yang terjadi pada setiap daun $R$. mucronata lebih besar dibanding daun $A$. marina, sehingga tingkat herbivori yang terjadi pada $R$. mucronata lebih besar dibanding daun $A$. marina.

Sampel daun $A$. marina muda utuh jumlahnya lebih banyak dibanding daun rusak, dengan kerusakan paling banyak terjadi pada kategori tinggi pohon 3-5 m. Berbeda dengan daun $A$. marina tua dengan jumlah daun utuh lebih sedikit dibanding daun yang rusak, namun kategori tinggi pohon yang mengalami kerusakan sama, terdapat pada tinggi pohon 3-5 $\mathrm{m}$. Hasil rerata tingkat herbivori spesies $A$. marina terendah ada pada daun muda dengan kategori tinggi pohon $<1 \mathrm{~m}$ sebesar 7,36\% (kisaran 0,10\%-29,36\%) dan tertinggi pada daun tua kategori tinggi pohon 35 m sebesar 13,26\% (kisaran 0,06\%-48,46\%).

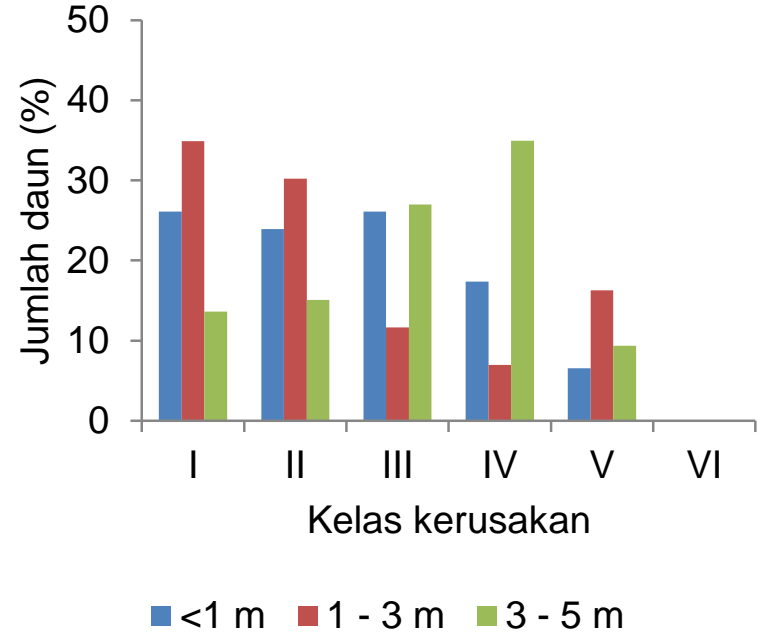

(a)

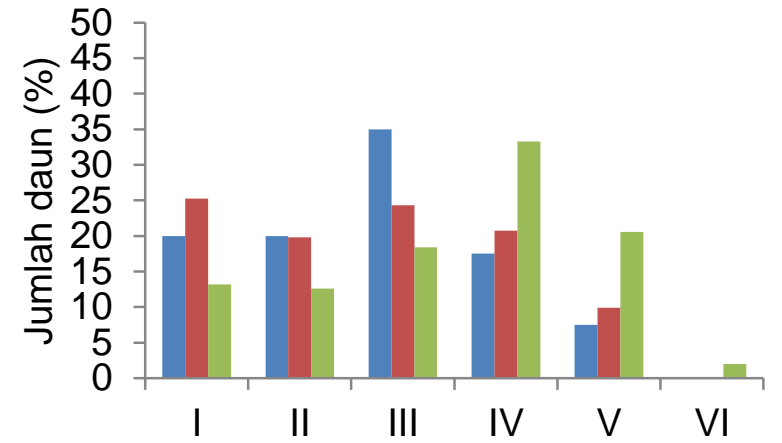

Kelas kerusakan

$\square<1 \mathrm{~m} \square 1-<3 \mathrm{~m}=3-5 \mathrm{~m}$

Gambar 1. Distribusi Jumlah Daun Rusak A. marina Berdasarkan Klasifikasi Tingkat Herbivori untuk (a). Daun Muda dan (b) Daun Tua.

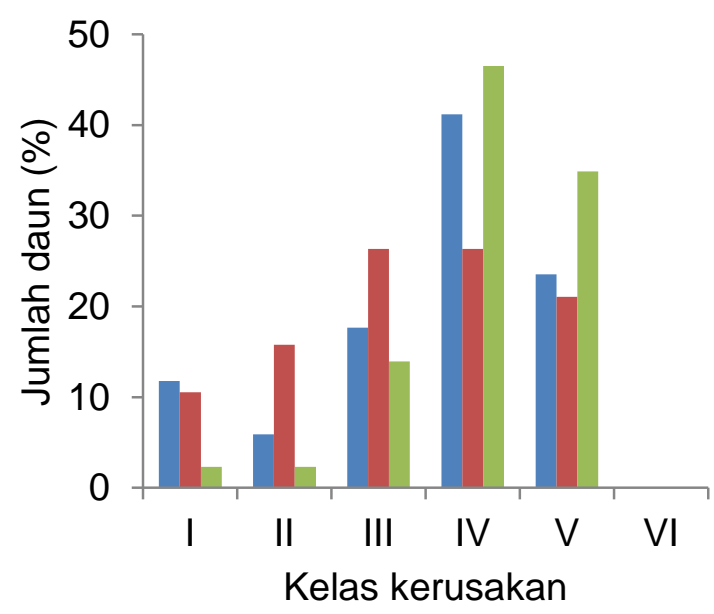

$\square<1 \mathrm{~m} \quad \square 1-3 \mathrm{~m} \quad \square 3-5 \mathrm{~m}$

(a)

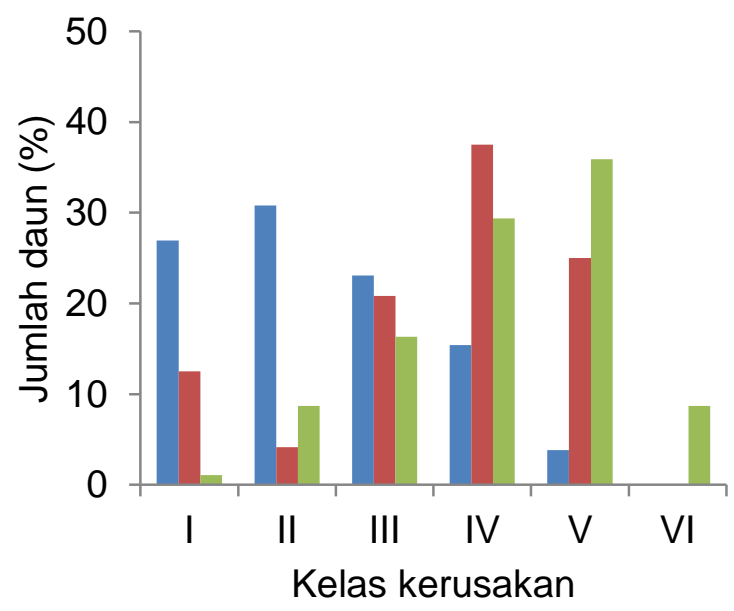

$\square<1 \mathrm{~m} \quad \square 1-<3 \mathrm{~m} \quad \square-5 \mathrm{~m}$

(b)

Gambar 2. Distribusi Jumlah Daun Rusak $R$. mucronata Berdasarkan Klasifikasi Tingkat Herbivori untuk (a). Daun Muda dan (b) Daun Tua. 
Daun muda mengalami herbivori lebih rendah dari daun tua, dengan rerata tingkat herbivori daun tua spesies $A$. marina sebesar $9,61 \%$ dan daun muda sebesar $8,34 \%$. Daun tua mengalami tingkat persentase herbivori yang lebih tinggi diduga karena daun muda lebih disukai oleh herbivor yang biasanya menyerang sejak daun masih dalam kondisi kuncup sehingga pada saat daun mengalami fase tua luasan yang rusak semakin besar karena ukurannya yang bertambah, hal ini sesuai dengan Robertson dan Duke (1987) yang menyatakan ukuran daun yang terjadi pemangsaan akan bertambah luas seiring dengan pertumbuhan daunnya.

Daun $R$. mucronata muda utuh jumlahnya lebih banyak dibanding daun rusak, dengan kerusakan paling banyak terjadi pada kategori tinggi pohon 3-5 $\mathrm{m}$. Sama halnya daun $R$. mucronata tua dengan jumlah daun utuh lebih banyak dibanding daun yang rusak, kategori tinggi pohon yang mengalami kerusakan pun sama terdapat pada tinggi pohon 3-5 $\mathrm{m}$. Hasil rerata tingkat herbivori spesies $R$. mucronata terendah ada pada daun tua dengan kategori tinggi pohon $<1 \mathrm{~m}$ sebesar 5,93\% (kisaran 0,23\%-21,59\%) dan tertinggi pada daun tua kategori tinggi pohon 35 m sebesar 19,69\% (kisaran 1,10\%-47,06\%). Rerata tingkat herbivori daun muda pada spesies $R$. mucronata lebih besar dari daun tua, dengan tingkat rerata daun muda $14,57 \%$ dan daun tua $12,95 \%$, diduga pada daun muda $R$. mucronata kandungan tannin yang dihasilkan lebih sedikit sehingga herbivor lebih menyukainya.

Soenardjo (2013) menyebutkan kandungan tannin pada daun tua dan daun muda mengalami perbedaan sehingga tingkat herbivori pada daun muda dan daun tua mengalami perbedaan pula. Hal ini sesuai dengan Nurcahyadi (2003) yang menyebutkan keberadaan tannin menyebabkan jaringan tumbuhan akan sulit dicerna herbivor. Pribadi (1998) menyatakan daun muda kemungkinan lebih disukai herbivor karena kandungan nitrogennya lebih tinggi, lunak, serta gampang dicerna. Daun muda mengalami tingkat herbivori yang lebih tinggi disebabkan herbivora menyukai daun muda. Kandungan serat daun muda yang lebih rendah dibanding daun tua menyebabkan daun muda lebih disukai untuk dikonsumsi. Fransworht dan Ellison (1993) menyatakan secara umum kualitas nutrisi memperlihatkan penurunan pada usia tua. Septyaningsih et al. (2014) menambahkan palatability daun diduga juga berpengaruh terhadap tingkat herbivori. Herbivor akan menyukai daun dengan nutrisi dan kelezatan yang lebih tinggi.

Hasil rerata tingkat herbivori tertinggi pada spesies $A$. marina terdapat pada kategori tinggi pohon 3-5 m, dengan hasil daun tua sebesar $13,26 \%$ dan daun muda sebesar $9,99 \%$, sedangkan persentase herbivori terendah terdapat pada ketinggian $<1 \mathrm{~m}$ dengan hasil daun muda sebesar $7,36 \%$ dan daun tua sebesar 5,93\%. Kategori tinggi pohon 3-5 m lebih banyak terkena herbivori diduga karena menerima lebih banyak sinar matahari dibanding ketinggian pohon $<1 \mathrm{~m}$. Hal ini sesuai dengan pernyataan Basset (1991) yang menyatakan biomasa yang dipindahkan oleh herbivora lebih besar pada daun yang tersinari matahari, selain itu daun yang lebih banyak terkena sinar matahari akan mendapatkan lebih banyak energi cahaya untuk proses fotosintesis, sehingga produk dari hasil fotosintesis yang dihasilkan juga lebih banyak. Herbivor akan lebih tertarik pada daun dengan kandungan nutrisi yang tinggi sehingga daun pada ketinggian 3-5 $\mathrm{m}$ akan lebih banyak terkena pemangsaan.

Persentase tingkat herbivori tertinggi pada spesies $R$. mucronata pada masing-masing kategori daun muda dan tua terdapat pada kategori tinggi pohon 3-5 $\mathrm{m}$, dengan hasil daun tua sebanyak $19,69 \%$ dan daun muda sebanyak $18,63 \%$. Tingkat herbivori terendah terdapat pada kategori tinggi pohon $<1 \mathrm{~m}$ dengan daun tua sebesar 5,93\%, sedangkan daun muda sebesar $7,36 \%$. Sama halnya dengan spesies $A$. marina tinggi pohon 3-5 m lebih banyak menerima sinar matahari sehingga akan mendapatkan lebih banyak energi untuk proses fotosintesis hasil produknya pun banyak. Hal ini akan menarik herbivori untuk memangsa daun pada kategori tinggi 3-5 $\mathrm{m}$ dari pada kategori tinggi pohon $<1 \mathrm{~m}$.

Berdasarkan hasil rerata tingkat herbivori dari kedua spesies menunjukkan adanya perbedaan pada daun muda lebih tinggi dari daun tua. Kategori tinggi pohon menunjukkan bahwa pohon dengan tinggi 3-5 m mengalami herbivori paling tinggi diantara kategori tinggi pohon lainnya, sedangkan kategori tinggi pohon $<1 \mathrm{~m}$ merupakan yang paling sedikit dimangsa oleh herbivor. 


\section{KESIMPULAN}

Kesimpulan dari penelitian ini adalah tingkat herbivori daun mangrove pada spesies Rhizophora mucronata lebih tinggi dibanding spesies Avicennia marina. Daun tua spesies Avicennia marina mengalami tingkat herbivori yang lebih tinggi dibanding daun mudanya. Daun tua maupun daun muda Avicennia marina mengalami tingkat herbivori paling tinggi pada kategori tinggi pohon $3-5 \mathrm{~m}$, sedangkan paling rendah ada pada kategori tinggi pohon $<1 \mathrm{~m}$. Tingkat herbivori daun tua pada spesies Rhizophora mucronata lebih rendah dibanding daun mudanya, sedangkan pada daun tua tingkat herbivori tertinggi terjadi pada kategori tinggi pohon 3-5m dan terendah pada tinggi pohon $<1 \mathrm{~m}$. Lain halnya dengan daun muda, tingkat herbivori terendah terdapat pada tinggi pohon 1-3m dan tertinggi pada tinggi pohon 3-5m.

\section{DAFTAR PUSTAKA}

Amalia, E. 2018. Tingkat Herbivori Daun Avicennia marina (Forssk.) Vierh dan Rhizophora mucronata di Vegetasi Mangrove Dusun Bogorame, Desa Timbulsloko, Kecamatan Sayung, Kabupaten Demak. [Skripsi]. Fakultas Perikanan dan IImu Kelautan, Universitas Diponegoro, Semarang, $60 \mathrm{hlm}$.

Basset, Y. 1991. The Spatial Distribution of Herbivory, Mines and Galls Within an Australian Rain Forest Tree. Biotropica. 23(3):271-281.

Cooke, F.P., Brown, J.P. \& Mole, S. 1984. Herbivory, Foliar Enzyme Inhibitors, Nitrogen and Leaf Structure of Young and Mature Leaves in a Tropical Forest. Biotropica.16(4):257-263.

Etikan, I., Musa, S.A. \& Alkassim, R.S. 2016. Comparison of Convience Sampling and Purposive Sampling. American Journal of Theoretical and Applied Statistics. 5(1):1-4.

Fransworth, E.J. \& Ellison, A.M. 1991. Patterns of Herbivory in Belizean Mangrove Swamps. Biotropica. 23(4b):555-567

Tropical Ecology. 9:435-453.

1993. Dynamics of Herbivory in Belizean Mangal. Journal of

1996. Spatial and Temporal Variability in Growth of Rhizophora Mangle Sampling on Coral Cays: Link with Variation in Isolation, Herbivory and Local Sedimentation Rate. Journal of Ecology, 84:717-731.

Johnstone, I.M. 1981. Consumption of Leaves by Herbivores in Mixed Mangrove Stands. Biotropica., 13(4): 252-259.

Kitamura, S., C. Anwar, A. Chaniago, dan S. Baba. 1997. Handbook of Mangrove in Indonesia: Bali \& Lombok. Denpasar. International Society for Mangrove Ecosystem, Denpasar, 119 hlm.

Lowman, M.D. 1984. An Assessment of Techniques for Measuring Herbivory: Is Rainforest Defoliation More Intense Than We Thought. Biotropica., 16(4):264-268.

McNaughton, S.J. 1983. Compensatory Plant Growth as a Response to Herbivory. Oikos. 40:329336.

Muharam. 2014. Penanaman Mangrove Sebagai Salah Satu Upaya Rehabilitasi Lahan dan Lingkungan di Kawasan Pesisir Pantai Utara Kabupaten Karawang. Jurnal IImiah Solusi. $1(1): 1-14$.

Murphy, D.H. 1990. The Natural History of Insect Herbivory on Mangrove Trees in and Near Singapore. Raffles Bulletin of Zoology. 38 (2):119-203.

Nurcahyadi, R. 2003. Studi Tingkat Herbivori Daun Mangrove di Desa Teluk Awur, Semat, dan Tanggul Tiare, Jepara. [Skripsi]. Fakultas Perikanan dan IImu Kelautan, Universitas Diponegoro, Semarang, $55 \mathrm{hlm}$.

Pribadi, R. 1998. The Ecology of Mangrove Vegetation in Bintuni Bay, Irian Jaya, Indonesia. [Thesis]. Departement of Biological and Molecular Sciences University of Stirling-Scotland.

Robertson, A.I. \& Duke, N.C. 1987. Mangrove as Nursery Sites: Comparisons of the Abudance and Species Composition of Fish and Crustaceans in Mangrove and Other Nearshore Habitats in Tropical Australia. Marine Biology., 96:193-205. 
Robot, R., Sangari J.R.R., \& Toloh, B.H. 2018. Visualisasi Data Digital Morfometrik Daun Avicennia marina di Perairan Pantai Tongkaina dan Bintauna. Jurnal IImiah Platax. 6(1):4253

Septyaningsih, E., Ardli, E.R., \& Widyastuti, A. 2014. Studi Morfometri dan Tingkat Herbivori Daun Mangrove di Segara Anakan Cilacap. Scripta Biologica, 1 (2):137-140.

Soenardjo, N. 2013. Pemangsaan daun Rhizophora stylosa Griff dan Avicennia marina (Forsk.) Vierh. Buletin Oseanografi Marina., 2:41-47.

Stowe, K.A. 1995. Intracown Distribution of Herbivore Damage on Laguncularia racemosa in a Tidally Influenced Riparian Habitat. Biotropica., 27(4):509-512. 